

\title{
Business and Human Rights Concerns in the Indonesian Textile Industry
}

\author{
Iman Prihandono and Fajri Hayu Religi \\ iprihandono@fh.unair.ac.id \\ Universitas Airlangga
}

\begin{abstract}
The textile industry substantially contributes to the national economic growth by employing 3.58 million workers, or 21.2 per cent of the total labour force in the manufacturing industry. Based on the Bank of Indonesia report, this industry significantly contributes to the Gross Domestic Product (GDP) of Indonesia. The contribution increased from Rp96.3trillion (US\$7billion) in 2010 to Rp139.4trillion (US\$10.2billion) in 2015. However, the textile industry in Indonesia does not only positively contribute to the country's economic growth; it also creates negative impacts, such as environmental issues. As will be explained further, these environmental impacts include environmental damage caused to the Citarum River and Sukoharjo. The textile industry's contribution to pollution is also high at a global level. Among the G20 countries, Indonesia is ranked 2nd for the highest levels of water pollution caused by the textile industry with 29.25 per cent, slightly below Turkey (32.21 per cent). Even though most of the international brands, such as GAP, $\mathrm{H} \& \mathrm{M}$, and Inditex, have already adopted human rights standards and policies, there are still many cases that show the failure of these companies to uphold human rights. For this reason, the implementation of international standards is needed to achieve a more sustainable textile industry. This article discusses business and human rights concerns about the Indonesian textile industry. It addresses several environmental issues caused by the textile industry, discusses human rights standards and policies in the textile industry, and finally shows possible ways of implementing such international standards in Indonesia.
\end{abstract}

Keywords: Textile Industry; Human Rights; Pollution; International Textile Industry CSR Standards.

\section{Introduction}

Indonesia is the tenth-largest textile exporter in the world. The textile industry has long been the major industry to absorb labour force in the country, substantially contributing to the national economic growth by employing 3.58 million workers, or 21.2 per cent of the total labour force of the manufacturing 
industry. ${ }^{1}$ Based on Industry Facts and Figures 2017, reported by the Ministry of Industry Republic of Indonesia, textile is one of the priority industries included in the ten national priority industrial groups in the National Industrial Development plan 2015-2035..$^{2}$ The textile business has been growing over the previous decade. Based on the report of the Bank of Indonesia, this industry significantly contributes to the Gross Domestic Product (GDP): the contribution increased from Rp 96.3 trillion (US\$ 7 billion) in 2010 to Rp 139.4 trillion (US\$ 10.2 billion) in 2015. ${ }^{3}$ Nonetheless, Indonesia only controls two per cent of the worldwide textile market, compared to the 35 per cent controlled by China. This difference can be explained by the many challenges faced by Indonesia to compete in the global market; these challenges include the inefficiencies in the upstream industries, which require more investment, a lack of technology, and adequate experts. Besides, the competition in the textile market is strong between nations in the ASEAN region, such as Cambodia, Vietnam, and Myanmar ${ }^{4}$

Since 2015, the increased production cost and the declining demand in the local market have caused factories to reduce their production. Additionally, the export market is also impuissant due to the slow increase of the clothing export to countries such as the United States (US), Japan, Germany, South Korea, the United Kingdom, Australia, China, Belgium, Canada, the United Arab Emirates, Malaysia, the Netherlands, Hong Kong, Italy, Spain, France, Singapore, Poland, Mexico and Thailand. In the first quarter of 2015, Indonesia's GDP produced by the

1 Dee Waluyo, 'Tumbuh Melampaui 3 Persen, Industri TPT.Pekerjakan 4 Juta Orang' (jpp. go.id, 2018) <https://jpp.go.id/ekonomi/industri/317908-tumbuh-melampaui-3-persen-industri-tptpekerjakan-4-juta-orang> accessed 6 April 2018.

2 Ministry of Industry Republic of Indonesia, 'Industry Facts \& Figures 2017' (kemenperin. go.id, 2017) <http://www.kemenperin.go.id/majalah/11/facts-and-figures-industri-indonesia> accessed 6 April 2018.[26].

3 Oxford Business Group, 'Indonesia Securing Trade Deals and Shifting Its Industrial Offerings towards Diverse and High Quality' (oxfordbusinessgroup.com) < https://oxfordbusinessgroup. com/analysis/threading-needle-securing-trade-deals-and-shifting-offerings-towards-diverse-andhigh-quality> accessed 6 April 2018.

4 Indonesia Investments, 'Textile Industry Indonesia' (indonesia-investments.com, 2016) $<$ https://www.indonesia-investments.com/id/business/industries-sectors/textile/item6896 $>$ accessed 6 April 2018. 
textile industry declined with a negative magnification of 0.98 per cent. The textile export similarly declined in the first quarter, to a worth of only US\$ 2.3 billion. The textile export is declining every year by US\$ 2.5 billion and only reached 18.3 per cent of the export target in 2015. ${ }^{5}$ Another challenge faced by Indonesia's textile export is the loading and unloading process at the Indonesian ports, as the average time of cargo handling - also known as the 'dwelling time'-remains high. In 2012, the average dwelling time was 6.5 days,${ }^{6}$ this number slightly improved to 3.6 days in 2017, remaining higher than the government's targeted dwelling time of 2.9 days. $^{7}$ Also, the existence of free trade agreements between other textile competitor countries such as Vietnam and Malaysia, and main export destinations, such as the European Union (EU) and the US, poses another challenge. Over 60 per cent of the total value of the Indonesian textile industry exports comes from knitted and crocheted apparel, textile accessories, and ready-to-use apparel. To boost the competitiveness of the Indonesian textile industry, the government established several schemes. For example, it proposed to remove value-added taxes on raw materials in order to cut the production costs. The governments also conducted bilateral trade discussions with the EU, proposing to agree upon a Comprehensive Economic Partnership Agreement (CEPA) to make export from Indonesia to the EU free from import duties. ${ }^{8}$

However, the textile industry in Indonesia does not only positively contribute to the country's economic growth; it also creates negative impacts linked to environmental issues. As will be explained further, these environmental impacts

\footnotetext{
5 Araminta Setyawati, 'Analysis: Indonesian Textile Industry Faces Formidable Challenges' (thejakartapost.com, 2015) <http://www.thejakartapost.com/news/2015/07/29/analysis-indonesiantextile-industry-faces-formidable-challenges.html> accessed 6 April 2018.

6 The Jakarta Post, 'Dwell-Time Target Set for Two Days in 2017' (thejakartapost.com, 2017) <https://www.thejakartapost.com/news/2017/01/04/dwell-time-target-set-for-two-daysin-2017.html > accessed 29 March 2019.

7 The Jakarta Post, 'Dwell Time at Ports Worsens to 3.5 Days: Official' (thejakartapost. com, 2017) < https://www.thejakartapost.com/news/2017/07/17/dwell-time-at-ports-worsens-to-35-days-official.html> accessed 29 March 2019.

8 Oxford Business Group, 'Indonesia's Textile Industry Looks to State for Boost' (oxfordbusinessgroup.com, 2016) <https://oxfordbusinessgroup.com/news/indonesia per centE2 per cent80 per cent99s-textile-industry-looks-state-boost> accessed 7 April 2018.
} 
include the environmental damages caused to Citarum River in West Java Province and Sukoharjo in Central Java. The textile industry's contribution to pollution is also high at a global level. Among the countries of the G20, Indonesia is ranked second for the highest levels of water pollution caused by the textile industry with 29.25 per cent, just slightly below Turkey (32.21 per cent). ${ }^{9}$ To reduce the environmental damages caused by the textile industry, the eco-labelling scheme could be imposed on textile producers to promote a more sustainable and pollution-free industry, as will be explained further in this article. ${ }^{10}$

Although most of the international brands, such as GAP, H\&M, and Inditex, already have adopted human rights standards and policies, there are still many cases that show the failure of these companies to uphold human rights in their international supply chain, including at production facilities in Indonesia. ${ }^{11}$ As a result, international standards must be implemented to achieve a more sustainable textile industry in Indonesia. This article will discuss businesses and human rights concerns in the Indonesian textile industry. It will address several environmental issues caused by the textile industry, discuss human rights standards and policies in the textile industry, and finally show possible ways of implementing these international standards - i.e., Eco Label and the Bangladesh Accord - in Indonesia.

\section{Environmental Issues in the Textile Industry}

\section{Environmental pollution of the Citarum River}

The Citarum River streams over 186 miles from the mountains of southern Java to the Java Sea, providing water to farmers and industry, and drinking water to over 25 million individuals.

\footnotetext{
9 Cristiana Tudor and Radu Petrariu Dorel Paraschiv, 'The Textile Industry and Sustainable Development: A Holt-Winters Forecasting Investigation for the Eastern European Area' (2015) 7 Sustainability.[1284].

${ }^{10}$ Ecolabel Index, 'Eco-Labels in Indonesia' (ecolabelindex.com, 2017) <http://www.ecolabelindex.com/ecolabels/?st=country,id $>$ accessed 4 April 2019.

11 M Faisal, 'Nasib Buruh H\&M Tak Secerah Produknya' (tirto.id, 2018) <https://tirto.id/ nasib-buruh-hm-tak-secerah-produknya-cLRS> accessed 4 April 2019.
} 
Map 1: Map of Citarum River



Source: A.S. Hardjasaputra, Citarum dalam Perspektif Sejarah.

For a considerable length of time now, the Citarum River has invariably been incorporated in various ecological gatherings as an example of one of the world's most polluted rivers, with an extremely poor water quality over most of its length. ${ }^{12}$ Of the over 2,000 industrial facilities that operate along the river's basin, 447 are part of the textile industry. ${ }^{13}$

In December 2015, two local community organizations named WALHI (Indonesian Forum for the Environment/ Wahana Environment Indonesia) and Pawapeling (Paguyuban Warga Peduli Lingkungan), with the support of Greenpeace

12 Chandni Vatvani, 'The Toxic Waste That Enters Indonesia's Citarum River, One of the World's Most Polluted' (channelnewsasia.com, 2018) < https://www.channelnewsasia.com/news/ asia/indonesia-citarum-river-worlds-most-polluted-toxic-waste-10124436> accessed 4 April 2019.

${ }^{13}$ Larry C. Price and Debbie M. Price, 'The Death of the Citarum River: Indonesia's Most Toxic Waterway' (pulitzercenter.org, 2017) <http://pulitzercenter.org/reporting/death-citarum-river-indonesias-most-toxic-waterway> accessed 7 April 2018. 
Southeast Indonesia, filed a lawsuit before the State Administrative Court in Bandung against (i) the Sumedang Regent's Decision Number 660.31/Kep.784IPLC/2014 regarding the permit of liquid waste disposal to Cikijing River - one of the Citarum River's tributaries - to PT. Five Star Textile Indonesia; (ii) Sumedang Regent's Decision Number 660.31/Kep.509-IPLC/2014 regarding the permit of liquid waste disposal to Cikijing River to PT. Kahatex; and (iii) Sumedang Regent's Decision Number 660.31/Kep.198-IPLC/2013 regarding the permit of liquid waste disposal to Cikijing River to PT. Insan Sandang Internusa. ${ }^{14}$

The plaintiffs argue that the liquid waste disposal by the three companies contaminated the Cikijing River. Although farmers often use the Cikijing River to irrigate their paddy fields and to support their livestock, a high level of heavy metals such as Chromium, Copper, Arsenic, Lead, and Cobalt have been found exceeding the safety standard. ${ }^{15}$ The occurrence of environmental pollution is indicated by decreasing land fertility and farm production output. ${ }^{16}$ It also caused damage to the crops-hollow grain-and fish. ${ }^{17}$ Moreover, there are strong indications that chemical pollution in the region has caused and increased the number of diseases. ${ }^{18} \mathrm{~A}$ report released by Padjadjaran University and Greenpeace on April 2016 stated that industrial wastewater that was used for irrigation had contaminated 2,300 acres of rice fields and caused economic losses approximating US\$ 866 million in over two decades. ${ }^{19}$

14 Greenpeace Indonesia, 'Puluhan Tahun Mencemari, 3 Perusahaan Teksil Digugat' (greenpeace.org, 2015) <http://www.greenpeace.org/seasia/id/press/releases/Puluhan-TahunMencemari-3-Perusahaan-Tekstil-Digugat> accessed 8 April 2018.

15 Environmental Justice Atlas, 'Textile Factories in Indonesia Pollute Water in Cikijing River, Tributary of Citarum River, Indonesia' (ejatlas.org, 2017) <https://ejatlas.org/conflict/ptkahatex-pt-insan-sandan-internusa-and-pt-five-star-textile> accessed 9 April 2018.

${ }_{16}$ Jonadab Ubochioma Chikaire Comfort Chigozie Godson-ibeji, 'Consequences of Environmental Pollution on Agricultural Productivity in Developing Countries: A Case of Nigeria' (2016) 5 International Journal of Agricultural and Food Research.[1-12].

${ }^{17}$ FAO, 'Prospects for the Environment' (fao.org) <www.fao.org/3/y3557e/y3557e11.htm> accessed 4 April 2019.

18 Dikanaya Tarahita and Muhammad Zulfikar Rakhmat, 'Indonesia's Citarum: The World's Most Polluted River' (thediplomat.com, 2018) < http://thediplomat.com/2018/04/indonesiascitarum-the-worlds-most-polluted-river/> accessed 4 April 2019.

19 Debbie M. Price, 'Worse for Wear: Indonesia's Textile Boom. The Rise of Fabric and Textile Manufacturing Brought Jobs to Indonesia's West Java Province. It Also Brought Object Pollution to the Citarum River' (undark.org, 2017) < https://undark.org/article/indonesia-textilescitarum-river-pollution> accessed 9 April 2018. 
Furthermore, in issuing the three licenses, the Sumedang Regent did not follow the applicable laws, such as Law Number 23 of 2007 on Environmental Management (as amended by Law Number 32 of 2009 on Environmental Protection and Management); Government Regulation Number 20 of 1990 on Water Pollution Control (as amended by the Government Regulation Number 82 of 2001 on Water Quality Management and Water Pollution Control), Government Regulation Number 35 Year 1991 on River (as amended by Government Regulation Number 38 Year 2011 on River), and Government Regulation Number 27 Year 1999 on the Analysis of Environmental Impacts (as amended by Government Regulation Number 27 Year 2012 on Environmental License). These licenses were also issued without prior environmental impact assessment on waste disposal and did not consider the water category of Cikijing River. Therefore, the disposal of liquid waste from the production of the three companies, which exceeded the environmental and legal standards, has declined the water quality of the Cikijing River.

The Bandung Administrative Court in its Decision Number 178/G/2015/ PTUN-BDG suspends, revokes, and cancels the permits of liquid waste disposal of PT.Five Star Textile, PT.Kahatex, and PT.Insan Sandang Internusa because the Sumedang Regent's Decisions in granting the permits for these three companies failed to fulfil the good governance and prudential principles under Indonesian Administrative Law. The defendants then appealed the decision to the Jakarta High Administrative Court arguing that the permits of liquid waste disposal were by Article 40 of Government Regulation No. 82 of 2001. Paragraph (1) of this Article stipulated that any business and/or activity that disposes wastewater into riverways should obtain written permission from the Regent or Mayor. Paragraph (2) also stipulated that application for the permit should be based on the results of an Environmental Impact Assessment or an Assessment Study on Environmental Management and Monitoring Efforts. The defendants argued that they had fulfilled these requirements. Nevertheless, the Jakarta High Administrative Court upheld the lower court's decisions through the Decision Number 237/B/2016/PT.TUN.JKT. 
Finally, the defendants appealed to the Supreme Court of Indonesia, arguing that other companies also dispose of liquid waste in the Cikijing River without obtaining waste disposal permits. The defendants indicated that they were willing to jointly assist in the recovery of the Cikijing River, but that this responsibility should also be imposed on other companies that do not hold waste disposal permits. The defendants argued that the Jakarta High Administrative Court Decision might not only have a negative impact on the water quality of the Cikijing River but also result in an economic loss from the closure of companies.

The Supreme Court through Decision Number 187/K/TUN/LH/2017 rejected the appeal and decided that the decision of the Jakarta High Administrative Court was correct and that there was no fault in the application of the law. The issuance of the Regent's Permit failed to consider the impact of wastewater disposal on animals, plants, soil, groundwater quality, and public health. Therefore, the three permits failed to meet the requirements as set forth in:

(i) Article 41 of the Government Regulation Number 82 of 2001;

(ii) Article 23 paragraph (2)(b) and (t) of the State Minister Regulation of the Environment No. 1 of 2010 on the governance of water pollution control;

(iii) The violation of the precautionary principle as stipulated in the provisions of Article 2(f) of Law No. 32 of 2009.

Unfortunately, these three companies have ever since continued their operations and still dispose of waste into the Cikijing River. PT. Kahatex, one of the largest textile companies in West Java, even received a new permit for liquid waste disposal within six months of the Supreme Court's decision. The company argued that the Sumedang Regent had never revoked their permit, even after the order made under the Supreme Court's decision. ${ }^{20}$

\section{Environmental damage in Sukoharjo}

Pollution due to the discharge of toxic and hazardous waste by the textile

\footnotetext{
${ }^{20}$ Dhio Faiz, 'Saat Kahatex Tantang Bupati Sumedang Cabut Izin Limbah' (cnnindonesia. com, 2018) <https:/www.cnnindonesia.com/nasional/20180326204822-75-286090/saat-kahatextantang-bupati-sumedang-cabut-izin-limbah> accessed 11 April 2018.
} 
industry has not only occurred in the Citarum River but also in other places in Indonesia, for example in Sukoharjo, Solo, Central Java, where pollution is caused by PT. Rayon Utama Makmur (PT. RUM), a subsidiary company of Sritex Group. Sritex Group was established in 1966 as the major textile producer in Indonesia. PT. RUM is a fibre supplier for Sritex Group; its production includes various kinds of raw textile materials. ${ }^{21}$ Sritex Fashion Division is part of the Sritex Group and is a sub-contractor of renowned international fashion brands, such as Zara, Guess, Uniqlo, H\&M, and Timberland. Sritex Group exports its apparel products to more than 50 countries. ${ }^{22}$ The case began when Sukoharjo residents protested, urging PT. RUM to control the air pollution stemming from its production site. ${ }^{23}$ The residents believed that there was a problem with the company's environmental management and suspected that it's waste management system was not appropriate. PT. RUM clarified that the smell and noise problems would only occur at the beginning of its operation and ensured that the liquid waste disposal into the river complied with the quality standard. ${ }^{24}$

The residents demanded the closure of PT. RUM because of the health problems caused by its air pollution. ${ }^{25}$ During a medical examination, it was discovered that 152 residents living near the factory had health problems such as

${ }^{21}$ PT. Sri Rejeki Isman Tbk, 'History' (sritex.co.id) <http://www.sritex.co.id/> accessed 11 April 2018.

${ }^{22}$ Sherr Rinn, 'Hukum Perdata Untuk Pencemar Lingkungan, Hukum Pidana Untuk Warga' (tirto.id, 2018) < https://tirto.id/hukum-perdata-untuk-pencemar-lingkungan-hukum-pidana-untukwarga-cGbK $>$ accessed 12 April 2018.

${ }^{23}$ Jakarta Post, 'Environmentalists Stage Rally in Front of Garment Company' (thejakartapost. com, 2018) <https://www.thejakartapost.com/news/2018/03/19/environmentalists-stage-rally-infront-of-garment-company.html $>$ accessed 4 April 2019.

${ }_{24}$ Bayu Ardi Isnanto, 'Menyoal Bau Busuk PT RUM Yang Menahun Dan Nasib Warga Sukoharjo' (news.detik.com, 2018) <https://news.detik.com/berita-jawa-tengah/d-4320452/ menyoal-bau-busuk-pt-rum-yang-menahun-dan-nasib-warga-sukoharjo $>$ accessed 4 April 2019. Ganug Nugroho Adi, 'More Activists Protesting Air Pollution in Sukoharjo Arrested' (thejakartapost. com, 2018) <https://www.thejakartapost.com/news/2018/03/14/more-activists-protesting-airpollution-in-sukoharjo-arrested.html> accessed 4 April 2019.

${ }_{25}$ Bayu Ardi Isnanto, 'Terdampak Bau Busuk Limbah PT.RUM, Warga Demo Di DPRD Sukoharjo' (news.detik.com, 2018) <https://news.detik.com/berita-jawa-tengah/d-3822569/ terdampak-bau-busuk-limbah-pt-rum-warga-demo-di-dprd-sukoharjo> accessed 12 April 2018. 
respiratory infection, dyspepsia, and dermatitis. ${ }^{26}$ PT. RUM responded by indicating its willingness to improve its waste treatment system and refinement process. ${ }^{27}$ The company was also willing to provide a Corporate Social Responsibility (CSR) program to improve the access to clean water, install air pollution detectors, and repair their waste disposal pipelines. ${ }^{28}$ On 24 February 2018, the Sukoharjo Regent issued Decree No. 660.1/207 ordering the closing of PT. RUM's factory. This Decree stated that the local government was imposing administrative sanctions by temporarily suspending PT. RUM's production for 18 months until the company would have improved its waste management system. PT. RUM was violating Law No. 32 of 2009 and Government Regulation No. 27 of 2012 on Environmental License by failing to install a Continuous Emission Monitoring system (CEM). PT. RUM also neglected to conduct emission control - resulting in air pollution - and to install the liquid waste filter in their disposal pipelines.

Furthermore, the Decree required PT. RUM to install a CEM on its air disposal unit and a liquid waste pipeline in the Sukoharjo. If PT. RUM failed to perform all the obligations stipulated in the Decree; further administrative sanctions might be imposed. ${ }^{29}$ Also, the Central Java Police is investigating the allegation of environmental pollution against PT. RUM following complaints by residents of Sukoharjo. Due to air pollution, PT. RUM is alleged of violating the State Minister Regulation No. 7 of 2012 on the Management of Fixed Source Emissions for Industrial Activities (Textile Fibre) Production. ${ }^{30}$

${ }^{26}$ Konradus Epa, 'Indonesian Villagers Battle Air, Water Pollution' (international.lacroix.com, 2018) <https://international.la-croix.com/news/indonesian-villagers-battle-air-waterpollution/7869> accessed 4 April 2019.

${ }^{27}$ Erlano Putra, 'PT RUM Klaim Sudah Laksanakan Kesepakatan' (sukoharjonews.com, 2019) <https://sukoharjonews.com/pt-rum-klaim-sudah-laksanakan-kesepakatan/> accessed 4 April 2019.

${ }_{28}$ Media Indonesia, 'PT.RUM Komit Benahi Sistem Limbah' (mediaindonesia.com, 2017) $<$ PT.RUM Komit Benahi Sistem Limbah> accessed 12 April 2018.

${ }^{29}$ Arie Sunaryo, 'Protes Bau Busuk PT.RUM, Warga Bakar Ban Dan Blockade Akses Masuk Pabrik' (merdeka.com, 2018) <https:/www.merdeka.com/peristiwa/protes-bau-busuk-pt-rumwarga-bakar-ban-dan-blokade-akses-masuk-pabrik.html> accessed 12 April 2018.

30 Imam Yuda, 'Polda Ambil Sampel Udara Yang Terkena Limbah PT.RUM' (jatengpos. com, 2018) <http://www.jatengpos.com/2018/03/polda-ambil-sampel-udara-yang-terkena-limbahpt-rum-900421> accessed 12 April 2018. 
Following these issues, the residents expressed their disagreement by protesting against PT. RUM, but this unfortunately ended in a chaotic situation. The Central Java Police also arrested Mr. Muhammad Hisbun Payu, an environmental activist. He was charged on the basis of Article 170 paragraph (1) of the Indonesian Penal Code for the destruction of the factory with a sentence of 12 years imprisonment and Article 187 paragraph (1) and (2) of the Penal Code for causing a fire in the factory resulting in a sentence of 15 years of imprisonment. ${ }^{31}$ However, the criminalization of the environmental activist is actually in violation of Article 66 of Law No. 32 of 2009, which stipulates that anyone advocating the right to a proper and healthy environment may not be charged with criminal or civil allegations. The elucidation of this Article further notes that this provision is intended to protect victims and whistle-blowers, and aims to obtain settlements in cases of pollution and environmental damage. In the end, the Semarang District Court gave the final verdict of sentencing the five activists with two years and three months imprisonment. They were found guilty of destructing PT. RUM's property, which is a criminal offense under the Indonesian Penal Code. ${ }^{32}$

\section{Human Rights Standards and Policies Adopted by Textile Companies}

To address the long-standing yet crucial cases of violations of human rights and the protection of environment conducted by textile companies in various jurisdictions, there is a need for a uniformed standard to limit, regulate, and sanction the perpetrators. This is precisely where international law plays a role. In June 2011, the UN Human Rights Council unanimously adopted the United Nations Guiding Principles on Business and Human Rights (UNGPs). This policy establishes that companies have a responsibility to carry out human rights due diligence across their

\footnotetext{
${ }^{31}$ Hendra Friana, 'Polisi Tangkap Aktivis Lingkungan Solo Atas Dugaan Perusakan Pabrik' (tirto.id, 2018) <https://tirto.id/polisi-tangkap-aktivis-lingkungan-solo-atas-dugaan-perusakanpabrik-cFFm> accessed 12 April 2018.

${ }^{32}$ Hesty Imaniar, '5 Terdakwa Perusakan PT RUM Sukoharjo Divonis' (jateng.tribunnews. com, 2018) <http://jateng.tribunnews.com/2018/08/07/5-terdakwa-perusakan-pt-rum-sukoharjo-divonis $>$ accessed 4 April 2019.
} 
operations, including in their supply chains. ${ }^{33}$

Today, a number of leading companies; including Adidas, ASOS, Benetton, C\&A, Esprit, Gap Inc., H\&M, Hugo Boss, Levi’s, Marks and Spencer, New Balance, Nike, Patagonia, Primark, and Puma; have made efforts to ensure compliance with international human rights standards and policies by disclosing names and addresses of their supplier factories and providing transparent information on their employees. ${ }^{34}$ These steps were taken in the aftermath of a report issued by Greenpeace showing that a number of global brands such as Adidas, H\&M, Gap, and others, have contributed to the air and water pollution in Citarum River through their local suppliers, one of which is PT. Gistex. ${ }^{35}$ In the following part, the writer will seek to outline the human rights standards, adopted by some international brands, to illustrate how they have enhanced awareness on companies' roles in upholding human rights virtues. This discussion, however, does not extend to a qualitative review of the companies' respective implementations of their adopted human rights standards, as this would require further research.

\section{GAP}

According to its website, GAP Inc. has established a human rights policy and is committed to respecting the international human rights provisions stated in the Universal Declaration of Human Rights (UDHR), the International Covenant on Civil and Political Rights (ICCPR), the International Covenant on Economic, Social and Cultural Rights (ICESCR) and the International Labour Organization (ILO) Declaration on Fundamental Principles and Rights at Work. GAP Inc. states that in its operation, GAP Inc. implements human rights due diligence

${ }^{33}$ United Nations Human Rights Office of the High Commissioner, 'Guiding Principles on Business and Human Rights' (ohchr.org, 2011) < http://www.ohchr.org/Documents/Publications/ GuidingPrinciplesBusinessHR_EN.pdf $>$ accessed 4 April 2019.

${ }^{34}$ Aruna Kashyap, 'When Clothing Labels Are a Matter of Life or Death' (hrw.org, 2018) $<$ https://www.hrw.org/news/2018/05/02/when-clothing-labels-are-matter-life-or-death $>$ accessed 4 April 2019.

35 Fathiyah Wardah, 'Greenpeace Tuding PT Gistex Cemari Sungai Citarum' (voaindonesia. com, 2013) <https://www.voaindonesia.com/a/greenpeace-tuding-pt-gistex-cemari-sungaicitarum/1643195.html> accessed 7 April 2019. 
processes, which are based on the UN Guiding Principles on Business, and Human Rights (UNGP). This is to show its commitment to respecting human rights and providing access to an effective remedy if ever the company causes or contributes to violations and adverse impacts. According to GAP Inc., this commitment is implemented globally and in all business relationships in GAP Inc.'s operations, product and services, and supply chain. ${ }^{36}$

There are three areas of priority for GAP Inc.: working conditions in its supply chain, the rights of employees, and the empowerment of women. The working conditions mechanism is listed under the Code of Conduct for Vendors, the rights of employees are stipulated under the Code of Conduct for Business Conduct, and women's empowerment is implemented to achieve the UN Sustainable Development Goals (UNSDGs) through "Personal Advancement \& Career Enhancement". Furthermore, to face the complex human right challenges, GAP Inc. partners with peers in collaborative initiatives; i.e., the Alliance for Bangladesh Worker Safety, the Ethical Trading Initiative, the ILO's Better Work Program, the Sustainable Apparel Coalition, the Zero Discharge of Hazardous Chemicals Initiative, and the UN Global Compact. ${ }^{37}$

GAP Inc. indicates that the application of human rights compliance is implemented through the Code of Conduct for Vendors that sets the basic requirements for all facilities that produce goods for GAP Inc., including its subsidiaries, affiliations, agents, and divisions. These requirements are based on internationally accepted labour standards, such as the ILO's conventions and UNGP. In regard to environmental aspects, GAP Inc. indicates that it manages its environmental impacts-i.e. energy and greenhouse gas emissions, air pollution, water consumption, water quality, wastewater, waste diversion and disposal, and chemical use and handling-through the "Environmental Management System" (EMS) and "Environmental Emergency Plan" (EEP). ${ }^{38}$

\footnotetext{
${ }^{36}$ GAP Inc, 'Human Rights Policy' (gapinc.com) < http://www.gapinc.com/content/attachments/sersite/HumanRightsPolicy_FINAL.pdf $>$ accessed 17 April 2018.[2].

37 ibid.[3].

${ }^{38}$ Gap Inc, 'Code of Vendor Conduct' (gapinc.com, 2016) < http://www.gapinc.com/content/ dam/gapincsite/documents/CodeofVendorConduct_FINAL.pdf $>$ accessed 17 April 2018.[10].
} 
GAP Inc. states that it implements a minimum age requirement for workers at 15 years of age. This age must be proved by official government-authenticated documentation. Children under 18 years of age shall be protected from working conditions that could pose risks to their health, safety or development-i.e., restrictions on night shifts and from all hazardous work. ${ }^{39}$ To prevent discrimination, GAP Inc. also states that it ensures that workers are hired based on their ability to perform their job and not on their appearances or beliefs. ${ }^{40}$

\section{H\&M}

The website of H\&M Group states that its human rights policy is based on the second pillar of the UNGP, namely that companies have a responsibility to respect human rights. $\mathrm{H} \& \mathrm{M}$ indicates that it implements "Human Rights Reporting" which apply to all entities within the H\&M Group. There are several international legal instruments, which are observed by H\&M Group to respect human rights: the UDHR, the ICCPR, the ICESCR, the ILO Declaration on Fundamental Principles and Rights at Work, the Children's Rights and Business Principles, the OECD Guidelines for Multinational Enterprises, and the UN Global Compact. Specifically, for vulnerable groups such as children and women, H\&M Group implements the United Nations Convention on the Rights of the Child and the United Nations Convention on the Elimination of Discrimination against Women. H\&M Group states that it not only prioritises the management of human rights at its operations and suppliers but also prevents human rights violations in its entire value chain. ${ }^{41}$

According to the H\&M Group, there are three key stakeholders that need to be considered for the implementation of its human rights policy: Employees, Suppliers, and Customers. To uphold its employees' rights, H\&M Group indicates

\footnotetext{
39 ibid.[14].

40 ibid.[19].

41 H\&M Group, 'Human Rights Policy' (sustainability.hm.com) <http://sustainability. hm.com/en/sustainability/downloads-resources/policies/policies/human-rights-policy.html> accessed 19 April 2018.
} 
that it complies with the national laws of the countries where it operates and applies established mechanisms concerning "Discrimination and Equality Policy" and the "Global Harassment Policy". H\&M Group also states that it implements a complaint procedure for the remedy of potential abuses faced by employees. For suppliers, H\&M Group states that it urges suppliers to ensure that human rights are respected in the supply chain for all business relationships and operational context through implementing a "Sustainability Commitment" mechanism. Lastly, for consumer protection, H\&M Group argues that it ensures the protection of data privacy and avoids discrimination as outlined in its "Discrimination and Equality Policy". ${ }^{42}$

According to the H\&M Group website, in the labour recruitment process, H\&M Group refers to standards stipulated in the ILO Conventions. For instance, for the protection of child labours, it refers to the ILO Conventions No. 138 on the health and safety of workers, No. 182 on workers' basic rights, and the UN Convention on the Rights of the Child. In regard to environmental issues, H\&M Group indicates that it requires all business partners in the supply chain to comply with all applicable environmental laws and regulations in the country where those companies operate. They must consider environmental permits and licenses including those concerning the handling of chemicals-as stipulated under the ILO Convention 170-water management and wastewater treatment, and waste management. ${ }^{43}$

In general, H\&M Group claims that it implements comprehensive standards and policies concerning human rights, these include: code of ethics (to detect violations of ethics); sustainability commitment (to promote sustainability performance in the supply chain); human rights policy (to ensure human rights enforcement in all processes); animal welfare and material ethics (for animal-based raw materials, to ensure traceability and compliance); chemical restrictions (to guide and support the

\footnotetext{
42 ibid.

43 H\&M Group, 'Code of Conduct' (sustainability.hm.com) <http://sustainability.hm.com/ content/dam/hm/about/documents/en/CSR/codeofconduct/Code per cent20of per cent20Conduct_ en.pdf $>$ accessed 19 April 2018.
} 
phase-out restricted chemicals used in the production line); and security policy (to achieve safety and security standards). ${ }^{44}$

\section{Inditex}

According to its website, Inditex expresses a commitment and responsibility to comply with human rights standards along its value chain. The company claims that this commitment is implemented through its "Human Rights Policy", which contains the compilation and update of its "Code of Conduct" and "Responsible Practices". Inditex states that it conducts due diligence and provides a complaint mechanism to identify and remedy any negative human rights impacts. ${ }^{45}$ Inditex also indicates its priority to be the protection of human rights and the environment through the implementation of a system of traceability and transparency by creating an ethical production process not only for the customers but also for all the workers and communities. The traceability of every aspect of the company's activity is implemented by the observation of how the products are designed, made and distributed; what the source of the materials in the supply chain is; how the health and safety conditions of the workers are; how energy and water are used; and what the company's tax contribution and social programs consist of. ${ }^{46}$

The "Human Rights Policy" is an important tool for Inditex in respecting international instruments on human rights. The instruments referred to by Inditex include the UDHR, the ICCPR, the ICESCR, the ILO Fundamental Conventions, the ILO Declaration on Fundamental Principles and Rights at Work, the Ten Principles of the UN Global Compact, the UNGP, and the OECD Guidelines for Multinational Enterprises. Additionally, Inditex claims that it also contributes to

${ }^{44}$ H\&M Group, 'The H\&M Group Sustainability Report 2016' (sustainability.hm.com, 2016) <https://sustainability.hm.com/content/dam/hm/about/documents/en/CSR/Report 2016/HM_ group_SustainabilityReport_2016_StandardsAndPolicies_en.pdf $>$ accessed 19 April 2018.

${ }^{45}$ Inditex, 'Our Protection of Human Rights' (inditex.com) $<$ https://www.inditex.com/howwe-do-business/right-to-wear/human-rights $>$ accessed 20 April 2018.

46 Inditex, 'Right to Wear' (inditex.com) <https://www.inditex.com/how-we-do-business/ right-to-wear> accessed 20 April 2018. 
UNSDG. ${ }^{47}$ Inditex indicates that it applies these principles to all stakeholders, such as employees, suppliers, and business partners; and particularly to the suppliers, which include all parties in the purchasing, manufacturing and finishing processes. Inditex established the "Code of Conduct and Responsible Practices", and the "Code of Conduct for Manufacturers and Suppliers", which are in compliance with the labour standards promoted by the ILO and in the UNGP. ${ }^{48}$ The latter contains provisions to ban forced labour, child labour, discrimination, harsh or inhuman treatment, excessive working hours; and ensure safe and hygienic working conditions, respect for freedom of association and collective bargaining, the pay of wages, regular employment, traceability of production, health and safety products, environmental awareness, confidentiality of information, and code implementation through transparency in accordance with legislation, conventions and agreements, verification of compliance, and the existence of a committee of ethics and a whistle blowing channel. ${ }^{49}$ Inditex also conducts partnerships with Canopy, Caritas, CEO Water Mandate, Fur Free Alliance, Organic Cotton Accelerator Sustainable Apparel Coalition, Textile Exchange, and WWF for promoting environmental protection.

\section{International Standards for Sustainable Textile Industry}

In the third section, it was demonstrated that many popular global brands had adopted human rights standards and policies. However, as we outlined in the second section, there remain problems concerning labour and human rights conditions. Reports from Asia Floor Wage Alliance (AFWA) allege that human rights abuse was discovered at a number of supplying factories for the textile industry. The first case was against GAP Inc., alleging that GAP Inc. failed to implement its social commitment to improve working conditions and provide a safe workplace for 150

47 Inditex, 'Policy on Human Rights' (inditex.com, 2016) <https:/www.inditex.com/ documents/10279/325624/Inditex+Policy+on+Human+Rights.pdf/0ec776a7-4b59-438b-bc2c42415760d0b4> accessed 20 April 2018.[5].

48 ibid.[10].

49 Inditex, 'Code of Conduct for Manufacturers and Suppliers Inditex Group' (inditex.com) $<$ https://www.inditex.com/documents/10279/241035/Inditex+Code+of+Conduct+for+Manufacturers+and+Suppliers/e23dde6a-4b0e-4e16-a2aa-68911d3032e7> accessed 20 April 2018. 
garment workers in Cambodia, India, and Indonesia. Moreover, GAP Inc. might also have been violating human rights by using non-standard working contracts with underpaid wages, not paying overtime, and failing to observe the health and safety conditions in the work environment. Additionally, GAP Inc. allegedly refused to pay compensation following the collapse of a factory in 2013, costing more than 1.100 workers their lives. ${ }^{50}$

The second case concerns an allegation of a human rights violation by the H\&M Group. The company was accused of paying too little wages, not paying overtime and having fixed-term contracts with workers in India and Cambodia. Cambodian workers were expected to work for two hours of overtime per day, and Indian workers were working from nine to seventeen hours a day. In addition, although 75 per cent of the textile workers were female, their contracts got terminated the moment they became pregnant. This happened in India and Cambodia; according to the report, 50 Indian female workers were fired because they were pregnant. ${ }^{51}$

Finally, the third case involving Zara (a member of Inditex), was initiated after a customer in Istanbul discovered a note in a clothing item indicating that workers weren't being paid at one of Zara's supplying companies: the Bravo Tekstil factory. The note illustrated the despair felt by these workers in their search for justice. The workers stated they needed an effective grievance mechanism because they had no possibility of reporting their complaints. Following this incident, Bravo Tekstil factory was shut down in 2016 after owing wages to its 140 workers. Unfortunately, Zara did not immediately respond to this situation. ${ }^{52}$

The AFWA Report and the three cases recorded therein show the failure of several popular western brands and local supplying textile companies to uphold human

50 Vibian Hendriksz, 'Gap and H\&M Fail to Uphold Human Rights in Supplier Factories' (fashionunited.uk, 2016) <https://fashionunited.uk/news/fashion/gap-and-h-m-fail-to-upholdhuman-rights-in-supplier-factories/2016052720559> accessed 21 April 2018.

51 ibid.

52 Ellen Wulfhost, 'Pleas for Help Sewn into Zara Clothes by Unpaid Workers "Just the Tip of the Iceberg", Warns Human Rights Expert" (independent.co.uk, 2017) < https://www. independent.co.uk/news/world/europe/zara-clothes-help-sewn-labels-tip-iceberg-human-rightsexpert-a8057206.html> accessed 21 April 2018. 
rights. Consequently, mandatory and uniformed international standards are needed to achieve a more sustainable textile industry. One development to be discussed is "Eco Label".

\section{Eco Label}

\section{Introduction}

An Eco label can be defined as a voluntarily method of improving environmental performance through labelling and certification. The goal of an Eco label is to identify products and/or services that are proven environmentally preferable within a specific product and service category. ${ }^{53}$ An Eco label is awarded by an impartial and independent third party for a specific category of products or services by determining environmental criteria and verifying compliance. According to the International Organization for Standardization (ISO), there are three types of Eco labels: (a) Type I: Eco labels - ISO 14024 (a voluntary scheme, third party certified, focusing on non-food products); (b) Type II: Self-declared environmental claims - ISO 14021 (informative environmental self-declaration claims); and (c) Type III: Environmental declarations-ISO 14025 (voluntary programs which provide quantified environmental data of a product set by a qualified third party and verified by that or another qualified third party). ${ }^{54}$ According to the OECD's empirical findings on the competition and multiplication of Eco labels in the apparel sectors, there is a strong competition between the existing Eco labels and an increasing trend in business-led programs and standards. ${ }^{55}$ The main objectives of an Eco label are the following:

(1) Protecting the environment. As a market-based instrument, an Eco label can influence consumer decisions and encourage production to bring about environmental improvements, such as efficient management of renewable

\footnotetext{
${ }^{53}$ Global Ecolabelling Network, 'What Is Ecolabelling?' (globalecolabelling.net) $<$ https:// globalecolabelling.net/what-is-eco-labelling/> accessed 21 April 2018.

${ }^{54}$ OECD, 'Environmental Labeling and Information Schemes; Policy Perspectives' (oecd. org, 2016) <https://www.oecd.org/env/policy-persectives-environmental-labelling-and-information-schemes.pdf $>$ accessed 21 April 2018.[3].

55 ibid.[11].
} 
resources; facilitating reduction, reuse and recycling of industrial, commercial and consumer waste; encouraging the protection of ecosystems and species diversity; and encouraging the proper management of chemicals in products.

(2) Encouraging environmentally sound innovation and leadership. By offering products that are environmental friendly, the businesses can establish or reinforce a market and a positive corporate image among consumers.

(3) Building consumer awareness of environmental issues. ${ }^{56}$ The mechanism of Eco label participation for companies is more or less the same as a certification mechanism, i.e., companies need to make an application and subsequently to submit their products/services for an evaluation and verification by a third party. If approved, the company pays a license fee for the use of an Eco label symbol for a specific term and will be regularly monitored by the managing agency. ${ }^{57}$

\section{The EU}

In the EU, the EU Ecolabel is claimed to be one of the most effective mechanisms to ensure that products contribute to the circular economy and are sustainable throughout their entire value chain, from the extraction of raw material to production, use, and disposal..$^{58}$ It is regulated under Regulation (EC) No 66/2010 of the European Parliament and the Council of 25 November 2009 on the EU Ecolabel. Article 6, Paragraph (3) stipulates the criteria that must be considered in regard to the most significant environmental impacts: the substitution of hazardous substances by safer substances; the potential of durable and reusable products to reduce environmental impacts; the net environmental balance between the environmental benefits and burdens; the social and ethical aspects related to international conventions and

\footnotetext{
${ }^{56}$ Global Ecolabelling Network, 'Information Paper: Introduction to Ecolabelling' (globalecolabelling.net, 2004) <https://globalecolabelling.net/assets/Uploads/intro-to-ecolabelling. pdf $>$ accessed 21 April 2018.[4].

${ }^{57}$ ibid.[3].

${ }^{58}$ European Commission Environment, 'EU Ecolabel: Reducing the Ecological Impact of Textile Dyeing' (ec.europa.eu) <http://ec.europa.eu/environment/ecolabel/> accessed 21 April 2018.
} 
agreements, such as relevant ILO standards and codes of conduct; the criteria established for other environmental labels; and the principle of reducing animal testing. In addition, even though the EU Ecolabel is a voluntary standard, Article 17 of this Regulation stipulates penalties to infringements of the provisions. ${ }^{59}$

The EU Commission issued Decision 2014/350/EU in order to set EU Ecolabel criteria specifically for textiles in June 2014, based on the requirements and assessment rules originally set out in 2009. According to this decision, the EU Ecolabel may be awarded to products that have a reduced environmental impact during their entire life cycle. In 2017, the EU Commission published an amended Decision concerning the ecological criteria applicable to awarding the EU Ecolabel for textile products: Commission Decision (EU) 2017/1392 of 25 July 2017 amending Decision 2014/350/EU and establishing the ecological criteria for the award of the EU Ecolabel for textile products. This amendment extended the scope of the assessment criteria applicable to textile fibres, yarn, fabric, and knitted panels. They now also include intermediate products intended for use in textile clothing, accessories and interior textiles; such as non-fibre elements, and cleaning products, which are woven or non-woven products made from textile fibres intended for the wet or dry cleaning of surfaces and the drying of kitchenware. ${ }^{60}$

\section{Indonesia}

In Indonesia, the "Indonesia Ecolabel certification" is developed based on various sources including the reference to ISO 14024 (environmental labels and declarations - Type I ecolabelling - Principles and guidelines), Law No. 32 Year 2009 on Environmental Protection and Management, Law No. 8 Year 1999 on Consumer Protection, and several international conventions and standards related

\footnotetext{
${ }^{59}$ Official Journal of the European Union, 'Regulation (EC) No 66/2010 of The European Parliament and of The Council' (eur-lex.europa.eu) <http://eur-lex.europa.eu/legal-content/EN/ TXT/?uri=CELEX:32010R0066> accessed 21 April 2018.

60 Official Journal of the European Union, 'Commission Decision (EU) 2017/1392' (eurlex.europa.eu, 2017) <http://eur-lex.europa.eu/legal-content/EN/TXT/?uri=CELEX:32017D1392> accessed 21 April 2018.
} 
to products and benchmarking with similar criteria on other Ecolabel programs. There are several institutions and stakeholders involved including the Ministry of Environment for formulating the application of the Ecolabel in Indonesia; the National Standardization Agency (BSN) for approving the criteria (standard) of the Eco label; the National Accreditation Committee to conduct the accreditation process applicable to the Ecolabel certification and the Ecolabel Certification Body which will have a task in evaluating and issuing the Eco label certificates. ${ }^{61}$ For textile and textile products, the Ecolabel is based on Indonesia National Standard (SNI) number 19-7188.4.1.

The Ecolabel certificate in Indonesia can be received after successfully complying with the requirements following these seven stages: 1) the registration for application of Ecolabel certification; 2) the initial inspection (pre-evaluation) to examine the completeness of the document. This is to examine whether or not the laboratory testing is required in the review process, the scope of factory inspection if required, determining the Ecolabel standard suitable for the product type, and other necessary conditions; 3 ) implementation of any corrective action by the company (if required), based on preliminary results (pre-evaluation); 4) field/factory inspection (Evaluation) to verify the fulfilment of all Ecolabel criteria; 5) implementation of any corrective action by the company (if required) based on the results of field inspection (Evaluation); 6) the decision of the certification committee concerning the issuance of the Ecolabel certification for the concerned product; and 7) the issuance of the Ecolabel certification. ${ }^{62}$

There are several Ecolabel institutes in Indonesia for the textile industry. These institutes are accredited to award companies a reliable label to produce products and textiles without any health hazards. One example is the Global Organic Textile Standard, which aims to unify the various existing standards; set new standards in

${ }^{61}$ The Ministry of Environment of the Republic of Indonesia, 'Sertifikasi KAN Dan Ekolabel Indonesia' (menlh.go.id) <http://www.menlh.go.id/sertifikasi-kan-dan-ekolabel-indonesia/> accessed 21 April 2018.

${ }^{62}$ Eko Waluyo MP, 'Mengenal Perkembangan Ekolabel Indonesia' (bernas.id, 2016) <https:// www.bernas.id/16985-mengenal-perkembangan-ekolabel-indonesia.html> accessed 21 April 2018. 
the field of Eco textile processing; and define world-wide recognised requirements that ensure the organic status of textiles, from the harvesting of the raw materials through environmentally and socially responsible manufacturing to the labelling, in order to provide a credible assurance to the end-user/consumer. ${ }^{63}$

\section{The Bangladesh Accord}

The Accord on Fire and Building Safety in Bangladesh (the Accord), signed on 15 May 2013, is an autonomous, lawfully authoritative agreement among brands and trade unions intended to work towards a safe and healthy Bangladeshi ReadyMade Garment Industry. The Accord was agreed upon following the Rana Plaza building collapse that caused the death of 1,100 people and harmed over 2,000. There are six key components in the Accord: (1) ensure a safe working environment in the Bangladeshi RMG industry; (2) independent inspection program supported by brands in which workers and trade unions are involved; (3) public disclosure of all factories, inspection reports, and corrective action plans; (4) ensure sufficient funds are available for remediation and to maintain sourcing relationships; (5) democratically elected health and safety committees in all factories to identify and act on health and safety risks; and (6) worker empowerment through an extensive training program, complaints mechanism and the right to refuse unsafe work. ${ }^{64}$

These components will be built on the "National Action Plan on Fire Safety" (NAP), which expressly welcomes the development and implementation by any stakeholder of any other activity that would constitute a meaningful contribution to improving fire safety in Bangladesh. The Accord sets the requirements of signatories' party, such as establishing common programs, liaison, and advisory structures. The signatories also welcomed a strong role for the ILO, through the Bangladesh office as well as through international programs, to ensure that both the National

${ }^{63}$ Ecolabel Index, 'All Ecolabels in Indonesia' (ecolabelindex.com) $<$ http://www.ecolabelindex.com/ecolabels/?st=country,id $>$ accessed 21 April 2018.

${ }^{64}$ Accord on Fire and Building Safety in Bangladesh, 'About the Accord' (bangladeshaccord. org) $<$ http://bangladeshaccord.org/about/> accessed 21 April 2018. 
Action Plan and the programs foreseen by the signatories of this Agreement, be implemented. The signatories agreed to develop and agree on an "Implementation Plan" within 45 days after signing the Accord. ${ }^{65}$

The follow-up Accord, i.e., the 2018 Accord, was established with a broader scope covering all suppliers producing for the signatory companies. If agents or other intermediaries become part of the signatory's business model, the signatory is responsible to assure that these intermediaries support the signatory's efforts to fulfil the obligations of the 2018 Accord, independent of whether the intermediaries signed the Accord themselves or not. Furthermore, a workers complaint process mechanism was established to enable workers to raise concerns on health and safety risks in a timely fashion, safely and confidentially. The 2018 Accord also ensures that the workers' rights to Freedom of Association are respected in relation to protecting their own safety. ${ }^{66}$

There are several textile companies operating in Indonesia that became a signatory of the Accord, including Inditex, H\&M, ESPRIT, and Carrefour. The effectiveness of the Accord is accounted for in its March 2017 Report. This report states that the Accord's training programs on workplace safety covered 482 factories, educating about 1 million workers. Moreover, 77 per cent of the safety hazards identified in initial inspections were reported or verified as having been fixed, but the Report also states that most factories still have substantial additional work to do to create completely safe working environments. ${ }^{67}$

\section{Better Buying and Ethical Trading Initiative (ETI) Bangladesh}

The "Better Buying" is a framework for suppliers - sub-contractors - to speak with retailers and brands about their on-going purchasing activities and

${ }^{65}$ Accord on Fire and Building Safety in Bangladesh, 'Accord on Fire and Building Safety in Bangladesh' (bangladeshaccord.org, 2013) <http://bangladeshaccord.org/wp-content/uploads/ the_accord.pdf $>$ accessed 21 April 2018.

${ }^{66}$ Accord on Fire and Building Safety in Bangladesh, '2018 Accord on Fire and Building Safety in Bangladesh: May 2018' (bangladeshaccord.org, 2017) <http://bangladeshaccord.org/ wp-content/uploads/2018-Accord-full-text.pdf $>$ accessed 21 April 2018.

${ }^{67}$ Aruna Kashyap, 'Bangladesh Accord: New Phase Should Protect Unions' (hrw.org, 2017) $<$ https://www.hrw.org/news/2017/05/11/bangladesh-accord-new-phase-should-protect-unions > accessed 21 April 2018. 
conditions that need improvement, without risking their business relationship. ${ }^{68}$ The general objective of the Better Buying scheme is to contribute to the industry-wide transformation of buyer purchasing practices so that business relationships support suppliers in providing decent workplace conditions. The Better Buying scheme aims to achieve its objective by widely disseminating detailed analyses on the purchasing practices of buying companies using supplier ratings submitted biannually and working with stakeholders to accelerate industry-wide improvements. ETI is a leading alliance of companies, trade unions, and NGOs that promote workers' rights around the globe. ETI has a membership of 59 apparel and textiles companies, including some of the major buyers in the sector. ${ }^{69}$

Better Buying and ETI are collaborating in Bangladesh to support and promote responsible buying practices within garment industry supply chains. ${ }^{70}$ This collaboration was programmed for 18 months by inviting Bangladesh suppliers to anonymously evaluate their buyers using the online rating platform of Better Buying. There are seven main aspects of purchasing practices: (1) planning and forecasting; (2) design and development; (3) cost and negotiation cost; (4) sourcing and order placement; (5) payment and terms; (6) management of the purchasing process; and (7) Corporate Social Responsibility harmonization. The ETI stated that the scores from Better Buying would serve as an autonomous method in determining the strengths and weaknesses of products. ${ }^{71}$ Through this mechanism, consumers, investors, civil society organizations, and other stakeholders may use the posted ratings to research brands and retailers to ensure that they are supporting companies that support fair working conditions and fair business relationships. ${ }^{72}$

${ }^{68}$ Better Buying, (betterbuying.org) < https://betterbuying.org/> accessed 4 April 2019.

${ }^{69}$ Ethical Trading Initiative, 'For More than 20 Years, ETI and Our Members Have Been a Driving Force in Ethical Trade.' (ethicaltrade.org) $<$ https://www.ethicaltrade.org/> accessed 4 April 2019.

70 Better Buying and ETI, 'Improving Garment Sector Buying Practices in Bangladesh' (betterbuying.org, 2018) < https://betterbuying.org/wp-content/uploads/2018/04/PRESS-RELEASE-BetterBuyingBGD-FINAL.pdf $>$ accessed 21 April 2018.

${ }^{71}$ ibid.

72 Better Buying, 'What We Do' (betterbuying.org) < https://betterbuying.org/what-we-do/> accessed 21 April 2018. 


\section{Conclusion}

As one of the ten biggest textile producers in the world and industry with promising job opportunities, the Indonesian textile industry contributes to the GDP and national economic growth. Nonetheless, the textile industry also has negative impacts, for instance environmental damage and labour abuse. These types of adverse impacts were described in several cases related to water and air pollution, such as the cases concerning the Cikijing River and the Sukoharjo village. In conducting their business activities, a number of textile brands and producers implement human rights standards and policies and apply them to all of their supply chain companies. These standards and policies are generally based on international legal instruments concerning human rights, such as the UDHR, the ICCPR, the ICESCR, the ILO Fundamental Rights Conventions, and the UNGP, covering environmental protection and labour rights. Although these brands and producers have human rights standards and policies in place, a number of studies and cases show the failure of the textile industry at large to uphold human rights and protect the environment. The adoption of mandatory and uniformed international standards in the textile industry is needed to improve human rights and environment conditions in the Indonesian textile industry. This could, for instance, be possible through the implementation of the Ecolabel certification to achieve more consumer and businesses awareness on the environmental impacts of products in the marketplace.

Finally, as the elaboration of the three cases in the second section revealed, law enforcement is certainly an area in which progress can be made in Indonesia. Strict enforcement of the Indonesian environmental laws, human rights, and labour laws, could definitely contribute to ensuring a safe working place within Indonesian textile companies and acting against the pollution of rivers, ground water, soil, and air. Moreover, compliance with such standards will facilitate the export of the Indonesian textile industry, as EU and US buyers will certainly appreciate the implementation of CSR standards. 


\section{Bibliography}

Accord on Fire and Building Safety in Bangladesh, 'About the Accord' (bangladeshaccord.org) <http://bangladeshaccord.org/about/> accessed 21 April 2018.

—_, 'Accord on Fire and Building Safety in Bangladesh' (bangladeshaccord.org, 2013) <http://bangladeshaccord.org/wp-content/uploads/the_accord.pdf $>$ accessed 21 April 2018.

- ' 2018 Accord on Fire and Building Safety in Bangladesh: May 2018' (bangladeshaccord.org, 2017) <http://bangladeshaccord.org/wp-content/ uploads/2018-Accord-full-text.pdf $>$ accessed 21 April 2018.

Araminta Setyawati, 'Analysis: Indonesian Textile Industry Faces Formidable Challenges' (thejakartapost.com, 2015) <http://www.thejakartapost.com/ news/2015/07/29/analysis-indonesian-textile-industry-faces-formidablechallenges.html> accessed 6 April 2018.

Arie Sunaryo, 'Protes Bau Busuk PT.RUM, Warga Bakar Ban Dan Blockade Akses Masuk Pabrik' (merdeka.com, 2018) <https://www.merdeka.com/peristiwa/ protes-bau-busuk-pt-rum-warga-bakar-ban-dan-blokade-akses-masukpabrik.html> accessed 12 April 2018.

Aruna Kashyap, 'Bangladesh Accord: New Phase Should Protect Unions' (hrw. org, 2017) < https://www.hrw.org/news/2017/05/11/bangladesh-accord-newphase-should-protect-unions $>$ accessed 21 April 2018.

_, 'When Clothing Labels Are a Matter of Life or Death' (hrw.org, 2018) $<$ https://www.hrw.org/news/2018/05/02/when-clothing-labels-are-matterlife-or-death> accessed 4 April 2019.

Bayu Ardi Isnanto, 'Menyoal Bau Busuk PT RUM Yang Menahun Dan Nasib Warga Sukoharjo' (news.detik.com, 2018) <https://news.detik.com/beritajawa-tengah/d-4320452/menyoal-bau-busuk-pt-rum-yang-menahun-dannasib-warga-sukoharjo $>$ accessed 4 April 2019.

—, 'Terdampak Bau Busuk Limbah PT.RUM, Warga Demo Di DPRD Sukoharjo' (news.detik.com, 2018) <https://news.detik.com/berita-jawatengah/d-3822569/terdampak-bau-busuk-limbah-pt-rum-warga-demo-didprd-sukoharjo $>$ accessed 12 April 2018.

Better Buying, 'H' (betterbuying.org) <https://betterbuying.org/> accessed 4 April 2019. 
—, 'What We Do' (betterbuying.org) <https://betterbuying.org/what-we-do/> accessed 21 April 2018.

Better Buying and ETI, 'Improving Garment Sector Buying Practices in Bangladesh' (betterbuying.org, 2018) <https://betterbuying.org/wp-content/ uploads/2018/04/PRESS-RELEASE-BetterBuyingBGD-FINAL.pdf> accessed 21 April 2018.

Chandni Vatvani, 'The Toxic Waste That Enters Indonesia's Citarum River, One of the World's Most Polluted' (channelnewsasia.com, 2018) <https://www. channelnewsasia.com/news/asia/indonesia-citarum-river-worlds-mostpolluted-toxic-waste-10124436> accessed 4 April 2019.

Comfort Chigozie Godson-ibeji JUC, 'Consequences of Environmental Pollution on Agricultural Productivity in Developing Countries: A Case of Nigeria' (2016) 5 International Journal of Agricultural and Food Research.

Debbie M. Price, 'Worse for Wear: Indonesia's Textile Boom. The Rise of Fabric and Textile Manufacturing Brought Jobs to Indonesia's West Java Province. It Also Brought Object Pollution to the Citarum River' (undark.org, 2017) $<$ https://undark.org/article/indonesia-textiles-citarum-river-pollution> accessed 9 April 2018.

Dee Waluyo, 'Tumbuh Melampaui 3 Persen, Industri TPT.Pekerjakan 4 Juta Orang' (jpp.go.id, 2018) <https://jpp.go.id/ekonomi/industri/317908-tumbuhmelampaui-3-persen-industri-tpt-pekerjakan-4-juta-orang $>$ accessed 6 April 2018.

Dhio Faiz, 'Saat Kahatex Tantang Bupati Sumedang Cabut Izin Limbah' (cnnindonesia.com, 2018) <https://www.cnnindonesia.com/ nasional/20180326204822-75-286090/saat-kahatex-tantang-bupatisumedang-cabut-izin-limbah> accessed 11 April 2018.

Dikanaya Tarahita and Muhammad Zulfikar Rakhmat, 'Indonesia's Citarum: The World's Most Polluted River' (thediplomat.com, 2018) <http://thediplomat. com/2018/04/indonesias-citarum-the-worlds-most-polluted-river/> accessed 4 April 2019.

Dorel Paraschiv CT and RP, 'The Textile Industry and Sustainable Development: A Holt-Winters Forecasting Investigation for the Eastern European Area' (2015) 7 Sustainability 1284.

Ecolabel Index, 'All Ecolabels in Indonesia' (ecolabelindex.com) $<$ http://www. ecolabelindex.com/ecolabels/?st=country,id $>$ accessed 21 April 2018. 
—, 'Eco-Labels in Indonesia' (ecolabelindex.com, 2017) <http://www. ecolabelindex.com/ecolabels/?st=country,id $>$ accessed 4 April 2019.

Eko Waluyo MP, 'Mengenal Perkembangan Ekolabel Indonesia' (bernas.id, 2016) $<$ https://www.bernas.id/16985-mengenal-perkembangan-ekolabel-indonesia. html $>$ accessed 21 April 2018.

Ellen Wulfhost, 'Pleas for Help Sewn into Zara Clothes by Unpaid Workers "Just the Tip of the Iceberg", Warns Human Rights Expert" (independent.co.uk, 2017) <https://www.independent.co.uk/news/world/europe/zara-clotheshelp-sewn-labels-tip-iceberg-human-rights-expert-a8057206.html $>$ accessed 21 April 2018.

Environmental Justice Atlas, 'Textile Factories in Indonesia Pollute Water in Cikijing River, Tributary of Citarum River, Indonesia' (ejatlas.org, 2017) $<$ https://ejatlas.org/conflict/pt-kahatex-pt-insan-sandan-internusa-and-ptfive-star-textile> accessed 9 April 2018.

Erlano Putra, 'PT RUM Klaim Sudah Laksanakan Kesepakatan' (sukoharjonews. com, 2019) <https://sukoharjonews.com/pt-rum-klaim-sudah-laksanakankesepakatan/> accessed 4 April 2019.

Ethical Trading Initiative, 'For More than 20 Years, ETI and Our Members Have Been a Driving Force in Ethical Trade.' (ethicaltrade.org) <https://www. ethicaltrade.org/> accessed 4 April 2019.

European Commission Environment, 'EU Ecolabel: Reducing the Ecological Impact of Textile Dyeing' (ec.europa.eu) $<\mathrm{http}$ ://ec.europa.eu/environment/ ecolabel/> accessed 21 April 2018.

FAO, 'Prospects for the Environment' (fao.org) <www.fao.org/3/y3557e/y3557e11. htm> accessed 4 April 2019.

Fathiyah Wardah, 'Greenpeace Tuding PT Gistex Cemari Sungai Citarum' (voaindonesia.com, 2013) <https://www.voaindonesia.com/a/greenpeacetuding-pt-gistex-cemari-sungai-citarum/1643195.html $>$ accessed 7 April 2019.

Ganug Nugroho Adi, 'More Activists Protesting Air Pollution in Sukoharjo Arrested' (thejakartapost.com, 2018) <https://www.thejakartapost.com/ news/2018/03/14/more-activists-protesting-air-pollution-in-sukoharjoarrested.html> accessed 4 April 2019.

Gap Inc, 'Code of Vendor Conduct' (gapinc.com, 2016) < http://www.gapinc.com/ content/dam/gapincsite/documents/CodeofVendorConduct_FINAL.pdf> 
accessed 17 April 2018.

GAP Inc, 'Human Rights Policy' (gapinc.com) < http:/www.gapinc.com/content/ attachments/sersite/HumanRightsPolicy_FINAL.pdf $>$ accessed 17 April 2018.

Global Ecolabelling Network, 'What Is Ecolabelling?' (globalecolabelling.net) $<$ https://globalecolabelling.net/what-is-eco-labelling/> accessed 21 April 2018.

- ' 'Information Paper: Introduction to Ecolabelling' (globalecolabelling.net, 2004) <https://globalecolabelling.net/assets/Uploads/intro-to-ecolabelling. pdf $>$ accessed 21 April 2018.

Greenpeace Indonesia, 'Puluhan Tahun Mencemari, 3 Perusahaan Teksil Digugat' (greenpeace.org, 2015) <http://www.greenpeace.org/seasia/id/press/releases/ Puluhan-Tahun-Mencemari-3-Perusahaan-Tekstil-Digugat $>$ accessed 8 April 2018.

H\&M Group, 'Code of Conduct' (sustainability.hm.com) $<$ http://sustainability. $\mathrm{hm} . \mathrm{com} /$ content/dam/hm/about/documents/en/CSR/codeofconduct/Code per cent20of per cent20Conduct_en.pdf> accessed 19 April 2018.

__ 'Human Rights Policy' (sustainability.hm.com) < http://sustainability.hm.com/ en/sustainability/downloads-resources/policies/policies/human-rights-policy. html> accessed 19 April 2018.

—_ 'The H\&M Group Sustainability Report 2016' (sustainability.hm.com, 2016) $<$ https://sustainability.hm.com/content/dam/hm/about/documents/en/CSR/ Report 2016/HM_group_SustainabilityReport_2016_StandardsAndPolicies_ en.pdf $>$ accessed 19 April 2018.

Hendra Friana, 'Polisi Tangkap Aktivis Lingkungan Solo Atas Dugaan Perusakan Pabrik' (tirto.id, 2018) <https://tirto.id/polisi-tangkap-aktivis-lingkungansolo-atas-dugaan-perusakan-pabrik-cFFm> accessed 12 April 2018.

Hesty Imaniar, '5 Terdakwa Perusakan PT RUM Sukoharjo Divonis' (jateng. tribunnews.com, 2018) <http://jateng.tribunnews.com/2018/08/07/5terdakwa-perusakan-pt-rum-sukoharjo-divonis> accessed 4 April 2019.

Imam Yuda, 'Polda Ambil Sampel Udara Yang Terkena Limbah PT.RUM' (jatengpos.com, 2018) <http://www.jatengpos.com/2018/03/polda-ambilsampel-udara-yang-terkena-limbah-pt-rum-900421> accessed 12 April 2018.

Inditex, 'Code of Conduct for Manufacturers and Suppliers Inditex Group' 
(inditex.com) $\quad<$ https://www.inditex.com/documents/10279/241035/ Inditex + Code + of + Conduct + for + Manufacturers + and + Suppliers/e23dde6a4b0e-4e16-a2aa-68911d3032e7> accessed 20 April 2018.

_- 'Our Protection of Human Rights' (inditex.com) < https://www.inditex.com/ how-we-do-business/right-to-wear/human-rights $>$ accessed 20 April 2018.

—, 'Right to Wear' (inditex.com) <https://www.inditex.com/how-we-dobusiness/right-to-wear $>$ accessed 20 April 2018.

—, 'Policy on Human Rights' (inditex.com, 2016) <https://www.inditex. com/documents/10279/325624/Inditex+Policy+on+Human+Rights. pdf/0ec776a7-4b59-438b-bc2c-42415760d0b4> accessed 20 April 2018.

Indonesia Investments, 'Textile Industry Indonesia' (indonesia-investments.com, 2016) <https://www.indonesia-investments.com/id/business/industriessectors/textile/item6896> accessed 6 April 2018.

Jakarta Post, 'Environmentalists Stage Rally in Front of Garment Company' (thejakartapost.com, 2018) <https://www.thejakartapost.com/ news/2018/03/19/environmentalists-stage-rally-in-front-of-garmentcompany.html> accessed 4 April 2019.

Konradus Epa, 'Indonesian Villagers Battle Air, Water Pollution' (international. la-croix.com, 2018) <https://international.la-croix.com/news/indonesianvillagers-battle-air-water-pollution/7869> accessed 4 April 2019.

Larry C. Price and Debbie M. Price, 'The Death of the Citarum River: Indonesia's Most Toxic Waterway' (pulitzercenter.org, 2017) < http://pulitzercenter.org/ reporting/death-citarum-river-indonesias-most-toxic-waterway $>$ accessed 7 April 2018.

M Faisal, 'Nasib Buruh H\&M Tak Secerah Produknya' (tirto.id, 2018) <https://tirto. id/nasib-buruh-hm-tak-secerah-produknya-cLRS $>$ accessed 4 April 2019.

Media Indonesia, 'PT.RUM Komit Benahi Sistem Limbah' (mediaindonesia.com, 2017) <PT.RUM Komit Benahi Sistem Limbah> accessed 12 April 2018.

Ministry of Industry Republic of Indonesia, 'Industry Facts \& Figures 2017' (kemenperin.go.id, 2017) $26<$ http://www.kemenperin.go.id/majalah/11/ facts-and-figures-industri-indonesia $>$ accessed 6 April 2018.

OECD, 'Environmental Labeling and Information Schemes; Policy Perspectives' (oecd.org, 2016) <https://www.oecd.org/env/policy-persectivesenvironmental-labelling-and-information-schemes.pdf $>$ accessed 21 April 
2018.

Official Journal of the European Union, 'Regulation (EC) No 66/2010 of The European Parliament and of The Council' (eur-lex.europa.eu) $<$ http://eur-lex. europa.eu/legal-content/EN/TXT/?uri=CELEX:32010R0066> accessed 21 April 2018.

—_ 'Commission Decision (EU) 2017/1392' (eur-lex.europa.eu, 2017) <http:// eur-lex.europa.eu/legal-content/EN/TXT/?uri=CELEX:32017D1392> accessed 21 April 2018.

Oxford Business Group, 'Indonesia Securing Trade Deals and Shifting Its Industrial Offerings towards Diverse and High Quality' (oxfordbusinessgroup.com) $<$ https://oxfordbusinessgroup.com/analysis/threading-needle-securing-tradedeals-and-shifting-offerings-towards-diverse-and-high-quality $>$ accessed 6 April 2018.

__ ' 'Indonesia's Textile Industry Looks to State for Boost' (oxfordbusinessgroup. com, 2016) $<$ https://oxfordbusinessgroup.com/news/indonesia per centE2 per cent80 per cent99s-textile-industry-looks-state-boost $>$ accessed 7 April 2018.

PT. Sri Rejeki Isman Tbk, 'History' (sritex.co.id) <http://www.sritex.co.id/> accessed 11 April 2018.

Sherr Rinn, 'Hukum Perdata Untuk Pencemar Lingkungan, Hukum Pidana Untuk Warga' (tirto.id, 2018) <https://tirto.id/hukum-perdata-untuk-pencemarlingkungan-hukum-pidana-untuk-warga-cGbK> accessed 12 April 2018.

The Jakarta Post, 'Dwell-Time Target Set for Two Days in 2017' (thejakartapost. com, 2017) <https://www.thejakartapost.com/news/2017/01/04/dwell-timetarget-set-for-two-days-in-2017.html> accessed 29 March 2019.

— , 'Dwell Time at Ports Worsens to 3.5 Days: Official' (thejakartapost.com, 2017) < https://www.thejakartapost.com/news/2017/07/17/dwell-time-atports-worsens-to-3-5-days-official.html $>$ accessed 29 March 2019.

The Ministry of Environment of the Republic of Indonesia, 'Sertifikasi KAN Dan Ekolabel Indonesia' (menlh.go.id) <http://www.menlh.go.id/sertifikasi-kandan-ekolabel-indonesia/> accessed 21 April 2018.

United Nations Human Rights Office of the High Commissioner, 'Guiding Principles on Business and Human Rights' (ohchr.org, 2011) <http://www. ohchr.org/Documents/Publications/GuidingPrinciplesBusinessHR_EN.pdf> accessed 4 April 2019. 
Vibian Hendriksz, 'Gap and H\&MFail to Uphold Human Rights in Supplier Factories' (fashionunited.uk, 2016) <https://fashionunited.uk/news/fashion/gap-andh-m-fail-to-uphold-human-rights-in-supplier-factories/2016052720559> accessed 21 April 2018.

HOW TO CITE: Iman Prihandono and Fajri Hayu Religi, 'Business and Human Rights Concerns in the Indonesian Textile Industry' (2019) 34 Yuridika. 
--This page is intentionally left blank-- 